\title{
Law, immigration and exclusion in Italy and Spain
}

\author{
Kitty Calavita \\ University of California, Irvine
}

\begin{abstract}
This article explores immigration law in Italy and Spain and focuses on the tension between the economic, social and legal marginalization of immigrants on one hand and the rhetorical emphasis on integration on the other. I argue that this tension reflects the contradiction in their political economy, in which the utility of a cheap, contingent - marginalized - workforce is countered by a political backlash against the inevitably impoverished and thus racialized immigrant population. Further, I argue that law plays a central role in this alchemy of economics, race, and exclusion. Laws that make immigrants' sojourn in the host society contingent on their willingness to perform marginalized labor guarantee immigrant otherness and racialization. Confronted with this powerful economics of alterité, and the legal infrastructure that supports it, even the most ambitious projects of immigrant «integration» are doomed.
\end{abstract}

Key words: immigrant marginalization, racialization, alterité, structural contradictions, institutionalized irregularity, post-fordism.

\section{Resumen. Legislación, inmigración y exclusión en Italia y España}

Este artículo explora la legislación sobre inmigración en Italia y España, focalizándose en la tensión entre la marginalización económica, social y legal de los inmigrantes, por un lado, y el énfasis retórico en la integración, por otro. Argumenta que dicha tensión refleja la contradicción en su política económica, en la que la utilidad de la fuerza de trabajo barata, contingente - marginalizada - es contrarrestada por la reacción política contra la inevitablemente empobrecida y racializada población inmigrante. Además, argumenta que la legislación juega un rol central en esta alquimia de la economía, la raza y la exclusión. Las leyes que provocan que la estancia de los inmigrantes en la sociedad receptora dependa de su disposición a emplearse en ocupaciones marginalizadas, garantizan la alteridad y la racialización de los inmigrantes. Debiendo enfrentarse a esta poderosa economía de la alteridad, y a la insfraestructura legal que le da soporte, incluso el más ambicioso proyecto de «integración» de los inmigrantes está condenado

Palabras clave: marginalización inmigrante, racialización, alteridad, contradicciones estructurales, irregularidad institucionalizada, post-fordismo.

\section{Table of Contents}

$\begin{aligned} \text { Introduction } & \text { Conclusion } \\ \text { Descriptive Overview } & \text { References }\end{aligned}$

The Economics of Alterité 


\section{Introduction}

President Bush and the United States Congress are currently attempting to enact immigration reform, focusing on guestworker programs and heightened border security. The attempt faces serious political obstacles, but even if a compromise can be reached the resulting policy is unlikely to significantly reduce the number of undocumented immigrants in the U.S. Indeed, despite the twists and turns of immigration policy historically in the U.S. and around the world, this policy arena is marked by its consistent failure (Cornelius et al., 2004; Massey et al., 2003).

Much of my work on immigration law and its enforcement (1989; 1992; 2005) has looked at the failure of the law to accomplish what it sets out to do, and I put those failures and constraints on enforcement in a structural context. For example, I have explored the ways the stubborn dilemmas of contemporary immigration law enforcement in the United States derive from structural contradictions. My work on the employer sanctions provision that was passed in the United States in 1986 (1989), highlighted the contradiction between recurring political demands to control the border versus the economic benefits of a cheap immigrant workforce. In my book on the 1950s Bracero Program (1992), I addressed the myriad ways such contradictions work themselves through enforcement agencies in the form of bureaucratic dilemmas, and discuss the troubles these dilemmas pose for enforcement officials on the ground.

When I first turned my attention to contemporary immigration in Spain and Italy, I brought this dialectical perspective with me. What I noticed right away - and what many others have said before me - is that Spanish and Italian immigration laws systematically marginalize immigrants, and that these marginalized workers are useful to employers (just as southern Spaniards and Italians had been useful thirty years earlier in northern Europe). At the same time though, policymakers make elaborate overtures to immigrant integration, which is a vague term that includes many different activities and dimensions, such as social and cultural inclusion for immigrants and tolerance by the local population.

In the book based on this research in Italy and Spain, Immigrants at the Margins: Law, Race, and Exclusion in Southern Europe (2005), I focus on this tension between the production of immigrant otherness and these integration efforts. In making sense of this tension, I draw from several sets of literature and theoretical perspectives, including the scholarship on law in action and the contradictions that get played out locally in daily administrative practices; the literature on anti-immigrant backlashes and fear of the «Other»; Critical Race Theory and discussions of racial formation more generally; and, the literature on citizenship, membership, and community within the context of contemporary globalization.

To summarize my argument very briefly, Italian and Spanish immigration laws emphasize integration, but at the same time welcome immigrants exclusively as workers, their legal status contingent on temporary work permits. 
These laws therefore pull in opposite directions at once, limiting immigrants' ability to put down roots by denying them permanent residence, while at the same time underwriting ambitious programs designed to integrate them into the social and cultural life of the community.

I argue that this tension is the manifestation in the legal and policy arena of broader contradictions in the political economy. That is, immigrants are useful as "Others» who are willing to work, or are compelled to work, under conditions and for wages that locals largely shun. The advantage of immigrants for these economies resides precisely in their Otherness or difference. At the same time, Otherness is the pivot on which anti-immigrant backlashes turn. Because, if marginalized immigrant workers are useful in part because they are marked by illegality, poverty, racialization and exclusion, this very marking, this highlighting of their difference, contributes to their distinction as a suspect population, and fuels backlash. So, immigration law simultaneously preserves Otherness, and must combat its political, social, and fiscal fallout. In concrete terms, it both constructs illegality and difference, and spends millions on doomed projects of integration.

A couple of anecdotes might be useful here, the first involving the infamous El Ejido riots and the second an anti-immigrant outburst in Salandra, Italy. On February 5, 2000, a group of local men in the agricultural town of El Ejido, in southern Spain, stormed the neighborhoods of North African farmworkers, burned tires, turned over cars, and ransacked a Muslim butchershop. The rampage continued for days, as the men, who were armed with knives and crowbars, set fire to immigrants' homes and stores, and went on what they called a "caza del moro» or "Arab hunt». By the time it was over, more than seventy people had been badly injured and hundreds left homeless (SOS Racismo, 2001; Foro Cívico Europeo, 2001).

The month before, in the southern Italian town of Salandra, angry locals had attacked an orphanage where 31 Albanian children were living. They carried rocks and clubs, and cried out, «Lynch the Albanians!». The mob of five hundred people were outraged that some of the Albanian boys «had looked at» some local girls during a neighborhood get-together (quoted in Bisso, 2000: 16).

I describe these two episodes here not because they are particularly unique, nor on the other hand because they are entirely representative of local attitudes. Instead, they serve as emblems of something both more subtle and more consequential — that is, the real and perceived status of immigrants as marginal and different «Others». Ghassan Hage (2000: 15) introduces his book about racialization in Australia by deconstructing graffiti on the walls of the university in Sydney, comprising a debate between anti-immigrationists and immigrant advocates. He notes that despite the ideological differences of the graffiti artists, they share the notion that immigrants are essentially «objects to be governed» and that it is the responsibility of Whites «to direct the traffic» (p. 17). Furthermore, there is «a structural affinity [...] between what is characterized as "racist", and the discourse of the dominant culture», even when that discourse calls for tolerance (p. 15). 
According to the same logic, these outbursts of anti-immigrant racism in Spain and Italy are the violent cousins of more civilized folk like «suspicion», "economic marginality», and even "tolerance». The kinship is «structural» because underlying them all is not just the common perception of immigrants as different, but the structural location of immigrants as third-world laborers in first-world economies that in fact makes them different. As we will see, law is complicit in this construction of difference.

Before examining the role of law and the specifics of the contradiction between integration and exclusion, the following section provides a brief summary of the demographics of immigration in Italy and Spain, the legal regimes, and immigrants' location in these economies. Following that, I will discuss in more detail the underlying contradictions, and then trace the logical and theoretical implications of what I call here the "economics of alterité».

\section{Descriptive Overview}

By 2003, there were 2.4 million legal and illegal immigrants living in Italy, with the vast majority coming from outside the European Union (Caritas, 2003). About one-third of these come from northern and sub-Saharan Africa and the rest come from just about every region of the world. Almost half of Italy's immigrants live in just two regions - Lombardy (the northern region, anchored by Milan) and Lazio (the central region around Rome). Even as the number of immigrants continues to climb, their distribution remains uneven, with over $80 \%$ residing in Italy's northern and central regions. Most gravitate to major cities, but some of the highest per capita concentrations are found in the small towns and villages of northeastern Italy (Ministro dell'Interno, 2001; ISMU-Cariplo, 2004: 355). The size and distribution of the undocumented population is difficult to gauge. Estimates have ranged from 250,000 (suggested by the Minister of the Interior), to 300,000 (Caritas), and 340,000 (the Organization for Cooperation and Economic Development) (Gruppo Abele, 2001).

One out of every four new hires in Italy is a non-EU immigrant ( $\mathrm{La}$ Gazzetta del Mezzogiorno, 2002: 14). They are street vendors, domestic workers, nurses, factory workers, gas station attendants, farmworkers, construction workers, dishwashers, foundry workers, metalworkers, sex workers, and office «errand-boys». But, they are clustered in several sectors, the primary ones being manufacturing (more immigrants work in manufacturing in Italy than anywhere else in the rest of Europe), construction, agriculture, domestic service, and other services.

Immigrants are found in a wide range of other sectors and niches as well. For example, they are an important component of the tourism industry, particularly the hotels and restaurants dotting the Adriatic coast that boom during the summer season but are virtually deserted by late August. In some areas, they are primarily street vendors, like the Senegalese who can be seen on the streets of large cities, selling cigarette lighters (Milan) and faux designer 
purses (Florence) and who ply the beaches of Tuscany and Sardinia in the summer.

One of Italy's most respected immigration experts argues, «The process of stabilization is perhaps the most significant aspect of immigration in Italy in the 1990s» (Pugliese, 2000: 65). By this he means that immigrants are an increasingly important part of the economy and are more and more likely to be legal residents and have regular jobs. Indeed, they are joining unions in record numbers. According to CGIL records, immigrant membership increased 22\% between 1998 and 2000 (Mottura, 2000). Interestingly, immigrants working in factories in Italy's southern regions are more likely to be unionized $(45 \%)$ than in the post-Fordist, small enterprises of the north (30\%). In some southern areas, union membership among factory workers is higher for immigrants than for local workers.

But, immigrant stabilization should not be exaggerated. For one thing, immigrants continue to play a pivotal role in Italy's vast underground economy. While just $15 \%$ of Italian workers labor in the submerged economy, 30\% of non-EU immigrants work there, and 62\% find their first job there (Eurispes, 2001: 59). And, not all of them are undocumented; according to one study, the majority of immigrants working in the underground economy have residence permits. Underscoring the importance of this off-the-books workforce, Italian employers save at least $\$ 13$ billion annually on taxes and social security payments by using immigrant workers in irregular employment (Osservatorio Ares, 2001).

Immigrants are often hired on a temporary or part-time basis. About $13 \%$ work in day labor, $15 \%$ are part-time, and another $10 \%$ are seasonal.(Caritas, 2003). In some regions and sectors - agriculture in the south is a conspicuous example — virtually all immigrant workers are seasonal day laborers. Even in the industrial heartland of the northeast, they are more likely than locals to be employed on a contingent basis (Ambrosini, 1999; 2001).

Spain had over 2.7 million legal immigrants by 2006, and, with just $11 \%$ of the European population, it now attracts more than $22 \%$ of its immigrants (Ministerio de Trabajo y Asuntos Sociales, 2006). The primary source region is Latin America (36\%), with Africa being the second largest source (24\%). A slightly larger share of Spain's immigrant population is thought to be unauthorized at any given point in time than in Italy, with most estimates hovering around 300,000 . Just under $40 \%$ of these are thought to be Moroccan, $25 \%$ South American, 12\% Sub-Saharan African, 8\% Chinese, and 8\% eastern European ${ }^{1}$.

Also as in Italy, women make up almost half of the immigrant population, with the proportions varying by nationality (Ministerio de Trabajo y Asuntos Sociales, 2006: 3). The «most feminized flows» of immigrants to Spain come

1. These estimates are gathered from a variety of NGO's operating in Spain and are cited in Amnesty International, 2002. 
from the Dominican Republic (about 80\%), Colombia (about 72\%), Ecuador and Brazil (almost 70\%), Equatorial Guinea (66\%), and the Philippines and Peru (65\% each) (Ribas-Mateos, 2000: 181; Ministerio de Trabajo y Asuntos Sociales, 2006: 3). Filipina and Peruvian women are more likely to arrive alone in search of domestic employment, while women from the Mahgreb countries and Pakistan usually accompany male migrants and, at least initially, tend not to work outside the home.

Most immigrants are concentrated in the wealthy region of Catalonia and in Madrid, with the third largest immigrant population found in the agricultural region of Andalusia, Spain's southernmost point (Ministerio de Trabajo y Asuntos Sociales, 2006: 4). With the Strait of Gibraltar separating Spain from Morocco by just eight miles, many who make this treacherous journey by sea remain in Andalusia and form the backbone of the region's agricultural workforce.

The proportion of immigrants in the workforce has increased every year for the last two decades. The number registered with the social security administration doubled in just two years from 2000-2002, with non-EU immigrants comprising four out of every ten new workers in the social security system. And, they are even more heavily represented in the underground economy, where non-EU immigrants account for at least $15 \%$ of the workforce (Tobarra, 2002: 10).

More important than their mere numbers, they fill critical niches in the economy - usually those that have been vacated by Spanish workers. Based on Interior Ministry data from 2001, immigrants are concentrated in agriculture $(33 \%)$, construction (15\%), domestic service (15\%), and the tourism industry $(11 \%)$, with a far smaller fraction in manufacturing than in Italy (Ministerio del Interior, 2001: 34). Mirroring this concentration and at the same time helping comprise it, of the 32,000 quota workers admitted in 2002, $53 \%$ went to agriculture, $20 \%$ to construction, and $11 \%$ to services of various kinds (SOS Racismo, 2002: 296). As in Italy, immigrants in Spain provide not just a supplemental workforce, but a particular kind of workforce, i. e. one that will do the jobs, and under conditions, that local workers no longer accept despite double-digit unemployment.

And as in Italy, the location of immigrants in different sectors varies across regions and localities. In Almería (the rural province in Andalusia where El Ejido is located), more than $90 \%$ of immigrants - mostly from the Maghreb countries - work in labor-intensive, hothouse agriculture, while in Barcelona they are distributed across construction, tourism, and a range of services, and in Madrid they are more likely to be found in domestic service. Wages and (rarely) benefits vary as well. What remains constant is that immigrants are found in the most precarious sectors and are usually compensated at lower rates than comparable local workers. Perhaps most precarious of all is the sex industry, where it is estimated that up to $70 \%$ of the mostly female workforce are immigrants.

Since Italy and Spain passed their first immigration laws in the mid-1980s, they have enacted amendments, revisions, and regulatory changes with dizzy- 
ing frequency. But, despite what seems like constant tinkering, several themes continue to characterize these policies. Above all, they are oriented towards immigrants as a labor supply, and contain relatively few provisions for permanent legal residency or naturalization. Quotas bring in immigrants to work in domestic service, agriculture, and construction for limited periods, after which they can apply for renewal, but they often fall into illegal status at some point. "Regularization» programs are implemented every few years, but this is temporary too, usually lasting only a year or two. To qualify for regularization, immigrants usually have to demonstrate that they are formally employed with a legitimate work contract —which is impossible for those working in the underground economy. Immigrants are marginalized in other words by what Lidia Santos (1993: 111) has called «institutionalized irregularity», or illegality that is structured into the immigration laws.

They are marginalized economically as well, as they work in jobs and under conditions that local workers generally reject. Their role in hothouse agriculture around El Ejido is a good example. The town of El Ejido is a creature of the new hothouse industry, and was officially incorporated in 1987. The area contains over 6500 hothouse «farms» —one for every six inhabitants. The vast immigrant workforce is almost entirely Moroccan, at least two-thirds of whom are undocumented. These workers are one of the prerequisites of the hothouse production system that requires the ability to increase the workforce at a moment's notice during periods of intense activity (Foro Cívico Europeo, 2001; Chattou, 2000). Contrary to what might be assumed about agricultural production in southern Spain, it is not based on age-old techniques. Instead, hothouse production is «a paradigmatic example of the workings of late capitalism» (SOS Racismo, 2001: 19).

In some ways, these hothouses are the agricultural equivalent of post-Fordist manufacturing in northern Italy. They are small-scale production units with intense levels of productivity and heavy investments in technology and equipment. The speed at which crops mature can be artificially increased by modifying temperatures and ventilation, and this requires that a supplemental labor force always be waiting in the wings. What contracts exist are oral. Wages even for legal immigrants, are about $\$ 20$ dollars a day, which is lower than the usual rate in this region that already has the lowest wages in Spain. Undocumented immigrants earn even less. These, and workers like them across Spain and Italy, have been called the "New Untouchables" (Harris, 1995), a class of outcasts whose utility resides precisely in their marginality — whose exclusion is, in effect, their passport.

\section{The Economics of Alterité}

Marginality is not just a characteristic that immigrants bring with them like a third-world passport that gains them admission and ushers them onto the fringes of the economy. Nor is it solely constructed through the legal system that denies them permanent legal residence and work permits. Instead, legal and 
economic marginality are mutually constituted — with the fragility of legal status contributing to immigrants' disempowerment vis a vis employers, and their concentration in the underground economy jeopardizing their ability to legalize.

But, we can take this one step further, because immigrants' location in the host economy reproduces their Otherness. Among other things, it ensures they will not have adequate health care, standard housing or other accoutrements of belonging, and invites racialized backlash. In other words, it is not just that longstanding inequalities among nations produce post-colonial subjects who provide cheap labor to first-world powers; rather, those inequalities - and those post-colonial subjects - are reproduced from within by a legal system that keeps their status temporary and contingent and an economic system that for the most part channels them into non-EU jobs and thus shores up their poverty and their difference.

This helps explain why there is no real contradiction between high unemployment rates in some areas like southern Italy and Spain and high rates of immigrant employment. They are in fact part of the same phenomenon of a late capitalism that, as Maurizio Ambrosini (2001) has put it, is made up of pre-Fordist and post-Fordist work, but little in between. It is noteworthy that three of the most important areas of immigrant employment are domestic service, agriculture, and, in northern Italy, small and medium-sized manufacturing shops. Despite the obvious differences in the work involved, what these sectors have in common is their embeddedness in the global, post-Fordist economy, the retention of essentially pre-Fordist labor relations, and rejection by many local workers.

Domestic service and agriculture were never part of the Fordist model of collective bargaining and government regulations associated with industrial employment in the mid-twentieth century. And, today they are an amalgam of pre-Fordist and post-Fordist conditions. For example, the environment and contours of domestic service have changed as women have joined the formal workforce in large numbers, but quasi-feudal employment relations in many places remain the norm. Agricultural employment too is a hybrid of pre and post-Fordist labor relations and employment structure - as exemplified by the El Ejido hothouses with their intense periods of productivity and short-term hiring, and global markets, price structure, and labor force. So too are the small manufacturing shops of northern and central Italy that hire so many immigrants and that have offset Italy's slow economic growth in the last two decades. In this context, as Ambrosini points out, «From a strictly economic point of view, the best immigrant is [...] one who is not integrated» (2001: 174; emphasis added).

In this "economics of alterite" ", economic marginalization is accompanied by and compounded by immigrants' criminalization and racialization. Tahar Ben Jelloun (1997: XIV) begins his fictionalized memoir of immigration to France, «Often with immigration it's the aesthetics that cause problems. Immigrants are not photogenic, except in cases of tragedy, when their image is 
all over the newspaper. Their looks are not reassuring». Integration programs are partly an effort to stave off the backlash against those who are not "photogenic», but who are nonetheless useful. The «aesthetics» problem derives from that utility, since by definition cheap and flexible labor bears the ugly stigma of poverty.

Immigrants are not just excluded, they are criminalized; they are not only different, they are dangerous. Above all, they are racialized. And, that racialization is part and parcel of the economics of alterité, as those who at other times and in other places were themselves declared racially inferior, now construct Others in that role.

Much evidence seems to validate fears of immigrant crime. In Spain, the proportion of the prison population who are foreigners is more than twenty-five times higher than the proportion of immigrants in the population. And, the statistics are comparable for Italy (Melossi, 2000a: 21). But, these statistics need to be carefully unpacked. For one thing, undocumented immigrants in Spain can be arrested and incarcerated for the sole offense of not having residence permits, and by 2002 almost half of all immigrant detentions were for administrative violations (Altozano, 2002: 26). More subtle than this criminalization of illegal status is the general stigma attached to third-world migrants. Manuel Delgado (2003: 221) explains that this stigma produces a heightened visibility. Arguing that immigrants are not accorded the privilege of fading into the background, Delgado contends that even those who want to be «tolerant» think:

Look at him! He is over there, let's watch him closely and let's try hard to understand him $[\ldots]$ to open ourselves to him, to tolerate him, to accept him..., but..., be careful, never take your eyes off of him.

(«Miradle! él está ahí, mirémoslo fijamente y dispongámonos todos a comprenderlo, a asumir su presencia, a abrirse a él, a tolerarlo, a aceptarlo..., pero..., cuidado, nunca lo perdáis de vista») (Delgado, 2003: 221).

This cognitive phenomenon in which our attention is drawn to those who are different, says Delgado, results in disproportionate police activity and criminalization, especially in a context where some nationalities are already thought to be predisposed to crime.

Of course, the existence of bias does not mean that immigrants do not commit crime, or even that they do not commit a disproportionate amount of crime. The Commission for Immigrant Integration in Italy reports that in the north, criminal activity by immigrants does appear to be higher than for Italians (Zincone, 2001). Melossi (2000b: 166) points out that some people may immigrate for the purpose of committing crimes much as others come for the conventional labor market. Others may be induced into crime by desperate circumstances after they arrive. As the Commission for Immigrant Integration says, "Deviance may represent one of the only avenues open to immigrants in 
the absence of the possibility of integration into society» (Zincone, 2001: 280). Immigrants are often young men too, a demographic category that is more disposed to crime in every population.

Whatever the causal factors that produce immigrant crime - demographics, labeling, hostility over mistreatment, economic desperation, or psychological distress - one thing is clear: immigrant crime draws a disproportionate response from law enforcement and in turn reaffirms collective stereotypes of the immigrant as a potential criminal. As Melossi (2000b: 152) has put it:

The stranger, being already at fault for his strangeness... will easily be the target for suspicion of all kinds of deviant and criminal acts. If only some stranger will engage in such acts...the viciousness of the circle will be perfect and the stranger will be found doubly guilty, for his strangeness and for his deviance.

A rich literature traces the use of the criminal justice system to mark off a group as Other and in the process define our own identity. Alison Young (1996) and Jonathan Simon (1993) have both discussed the "outlaw as other». And, Young (1996) describes the social exclusion of these Others as a counterproductive effort at community building and identity formation. In the context of immigration, this mutual constitution of the criminal, the «other», and «us», is particularly potent, and is inevitably shot through with race.

Critical Race Theory explains that race is socially constructed. While there are all kinds of phenotypical differences among us, the social meaning of those differences, their groupings, and their hierarchical arrangement - their racialization - are constructed through the interaction of social, economic, political, and ideological processes. Ian Haney-Lopez (2003: 119) describes race thinking as akin to "common sense» in that «most people treat racial beliefs as timeless truths». As Omi and Winant (1986: X) say in their discussion of racial formation in the United States, "Race is not an essence. It is not "something fixed, concrete, and objective"». Instead, it is "a set of social meanings", woven from the fabric of social and economic life.

Contemporary immigrants in Italy and Spain are racialized through several interrelated processes, the broad outlines of which are similar to those of previous times and places — including those that applied to Spanish and Italian immigrants to America and northern Europe over the last century. Sometimes the racialization is overt, as when a Lega Nord official in Italy calls for separate train compartments for "extracomunitari». More often it is subtle, hovering just beneath the surface of the collective stereotypes and poverty that lead to prison for so many and that symbolically criminalize so many others.

Turning on its head Alessandro Dal Lago's (1999) notion of the immigrant as non-person, Manuel Delgado (2003: 218) notes, «The vast majority of people we come in contact with in public spaces are... "non-persons"”, in the sense that they are merely «extras» on a set and thus enjoy the absence of scrutiny. But, the stigma of difference marks non-EU immigrants as highly visible 
Others who are not only suspicious by virtue of their difference, but conspicuous in their strangeness. According to Delgado (p. 222), "This is the primordial act of racism of our day, denying certain people [...] the possibility of passing unnoticed» («Ése es el acto primordial del racismo de nuestros días, negarle a ciertas personas calificadas de diferentes, la posibilidad de pasar desapercibidas»). Subject to economic marginality and its myriad deprivations, assumed to be prone to crime, and always in the spotlight, immigrants' criminalization is over-determined by a factor of three, with the common denominator being their racialization.

The markers of such racial distinctions are often somatic, but it is increasingly unfashionable to justify racial rankings on the grounds of biology. Instead, culture - essentialized and suffused with biological insinuations - has become its proxy. In what Balibar (1991) calls «racism without race», presumed cultural and religious differences now substitute for biologically-grounded racial categories. But, I would argue, these cultural and religious differences are given meaning in large part by the economic marginality that is woven through them.

Race in this context is not just socially constructed; it is more precisely economically and materially constructed, as the social meaning ascribed to both somatic difference and cultural Otherness is grounded in material conditions. That is, immigrants are racialized, and their cultures highlighted as problematically distinct, to the extent that they are economically Other. Thus, for example, southern Italian workers in northern Europe in the 1950 s and 60s were deemed racially and culturally Other until Italy joined the club of First-World nations, and southern Italians no longer provided what was essentially Third-World labor to the rest of Europe. Tahar Ben Jelloun (1997: XIV-XV) makes the point that «ethnic and cultural difference» by themselves do not elicit racism; instead, their connection with poverty does. He writes:

Poverty has never been well-received.... At most, difference is accepted under condition that the person be rich, under condition that he has the means to disguise it and pass unobserved. Be different, but be rich! Whoever has no other riches than their ethnic and cultural difference are consigned to humiliation and every form of racism.

Law plays an important supporting role in this economics of alterité, as the quota system channels immigrants from the Third World to what might loosely be referred to as «non-EU jobs», or more precisely, jobs offerred under conditions that most EU members shun. Conversely, those who do not enter through these channels are often by definition illegal and subject to even greater degrees of economic marginality, relegated as they are to the undergound economy. Economic marginality is thus institutionalized through law. But, immigrants' position in the economy, having been secured by law, inevitably reproduces the visible markers of poverty in Italy, Spain, and elsewhere. The unseemly 
stigmata of poverty are what make immigrants «not aesthetic». And, these stigmata are integral to immigrants' ongoing racialization, much as the economic function and resulting poverty of African-Americans and third-world immigrants in the United States over the last several centuries cannot be disassociated from their racialization.

\section{Conclusion}

Law plays a central role in this alchemy of economics, race, and exclusion. As we have seen, immigrants' Otherness is shored up by laws that formally codify them as different at several levels. Perhaps most important, Spanish and Italian laws make it difficult for Third World immigrants to gain admission as legal residents outside of the quota system that is largely confined to those willing to work in agriculture, domestic help, and construction, i.e. those sectors where wages and working conditions are inadequate to attract sufficient local workers. These laws thus guarantee that most immigrant workers labor under conditions that are largely shunned by the indigenous working class, an arrangement that reproduces their economic otherness and related racialization. Confronted with this powerful economics of alterité, and the legal infrastructure that supports it, even the most ambitious policies of immigrant integration are doomed, sabotaged not just by racist fearmongers but by the law itself.

It is such inherent contradictions between the construction of immigrant difference and efforts at integration, reflecting broader tensions in the political economy, that help explain the dismal failure of immigration policymakers to accomplish what they set out to do. As the U.S. Congress considers establishing a program of temporary work permits, bringing it closer to the southern European model, we can expect that rather than solving the immigration problem, they will have simply launched a new set of contradictions.

\section{References}

AltozAnO, Manuel (2002). «Los inmigrantes irregulares detenidos en 4 meses se duplican en relación con 2001». El País, July 12: 26.

Ambrosini, Maurizio (1996). «Le Sfide della Cittadinanza, Ripensare le Politiche Sociali nell'Epoca della Globalizzazione Economica». Politiche Sociali e Servizi, volume 1: 7-24.

- Utili Invasori: L’inserimento degli Immigrati nel Mercato del Lavoro. Milan: Franco Angeli.

- (2001). La Fatica di Integrarsi: Immigrati e Lavoro in Italia. Bologna: Il Mulino. AMNESTY INTERNATIONAL (2002). «Spain: Crisis of Identity, Race-Related Torture, and Ill Treatment by State Agents». <www.amnesty.org>. April 16.

Balibar, Etienne (1991). "Is There a "Neo-Racism"?». In: Balibar, Etienne; Wallerstein, Immanuel (eds.). Race, Nation, Class: Ambiguous Identities. New York: Verso Press, p. 17-28. 
Bisso, Marino (2000). «Linciamo gli Albanesi». La Repubblica, January 14: 16.

CALAVITA, Kitty (1989). "The Contradictions of Immigration Lawmaking: The Immigration Reform and Control Act of 1986». Law and Policy, volume 11, number 1 .

- (1992). Inside the State: The Bracero Program, Immigration, and the INS. New York: Routledge.

- (2005). Immigrants at the Margins: Law, Race, and Exclusion in Southern Europe. Cambridge: Cambridge University Press.

CARITAS (2003). Immigrazione: Dossier Statistico 2003. Rome: Edizioni Anterem.

Chattou, Zoubir (2000). «Los Trabajadores Agrícolas Marroquíes de El Ejido». Migraciones, volume 8: 203-229.

Cornelius, Wayne A.; Takeyuki Tsuda, Philip L. Martin; Hollifield, James F. (2004). Controlling Immigration: A Global Perspective. Stanford, California: Stanford University Press.

Dal Lago, Alessandro (1999). Non-Persone: L'esclusione dei Migranti in una Societá Globale. Milan: Interzone.

Delgado, Manuel (2003). «Criminalización de los Inmigrantes?». In: BerGaLLI, Roberto (ed.). Actas de las Jornadas del Graduat en Criminologia i Politica Criminal. Universitat de Barcelona, p. 217-225.

EURISPES (2001). Rapporto Italia 2001. Rome: Ufficio Stampa Eurispes.

Foro Civico Europeo. Comité de Defensa de los Refugiados e Inmigrantes (2001). El Ejido: Tierra Sin Ley. Estella-Navarra: Gráficas Lizarra.

GRUPPo Abele (2001). Annuario Sociale 2001. Milan: Feltrinelli Editore.

HaGe, Ghassan (2001). White Nation: Fantasies of White Supremacy in a Multicultural Society. New York: Routledge.

HaneY-LOPEZ, Ian (2003). Racism on Trial: The Chicago Fight for Justice. Cambridge, Massachusetts: Belknap Press.

HARRIS, Nigel (1995). The New Untouchables: Immigration and the New World Worker. London: St. Martin's Press.

ISMU-Cariplo (2004). Nono Rapporto sulle Migrazioni. Milan: Franco Angeli.

Jelloun, Tahar Ben (1997). Le Pareti della Solitudine. Turin: Giulio Einaudi Editore.

MASSEY, Douglas S.; DuRAND, Jorge; MALONE, Nolan J. Beyond Smoke and Mirrors: Mexican Immigration in an Era of Economic Integration. New York: Russell Sage Foundation.

Melossi, Dario (2000a). "Alla Ricerca di una "Vita Tranquilla": Immigrazione, Criminalitá e Italian Way of Life». Quaderni di Cittá Sicure, volume 1: 17-69.

- (2000b). «The Other in the New Europe: Migrations, Deviance, Social Control». In: Green, Penny; Rutherford, Andrew (eds.). Criminal Policy in Transition. Oxford: Hart Publishing, p. 151-166.

Ministerio de Trabajo y Asuntos Sociales (2006). «Estadístico de Extranjería e Inmigración». Observatorio Permanente de la Inmigración, volume 7 (January).

MINISTERIO DEL INTERIOR (2001). Balance 2000: Extranjería e Inmigración. Madrid: Oficina de Relaciones Informativas y Sociales.

Ministro Dell'InTERno (2001). Rapporto del Ministro dell'Interno sullo Stato della Sicurezza in Italia. Bologna: Il Mulino.

MotTura, Giovanni (2000). «Immigrati e Sindacato». In: PUGLIESE, Enrico (ed.). Rapporto Immigrazione: Lavoro, Sindacato, Societá. Rome: Ediesse, p. 113-134.

OMI, Michael; WINANT, Howard (1986). Racial Formation in the United States: From the 1960s to the 1980s. New York: Routledge and Kegan Paul. 
OSSERVATORIO ARes (2001). «I Dati dell'Osservatorio Ares 2000», presented at a conference on Flussi Migratori e Politiche per la Salute, Sicily, March 26.

Pugliese, Enrico (2000). "Gli Immigrati nel Mercato del Lavoro e nella Struttura dell'Occupazione». In: PUGLIESE, Enrico (ed.). Rapporto Immigrazione: Lavoro, Sindacato, Societá, Rome: Ediesse, p. 65-87.

Ribas-MateOS, Natalia (2000). «Female Birds of Passage: Leaving and Settling in Spain». In: ANTHIAS, Floya; LAZARIDIS, Gabriella (eds.). Gender and Migration in Southern Europe: Women on the Move, New York: Berg, p. 173-197.

SANTOS, Lidia (1993). «Elementos Jurídicos de la Integración de los Extranjeros». In: TAPINOS, Georges (ed.). Inmigración e Integración en Europa. Barcelona: Itinera Libros, p. 91-125.

SimON, Jonathan (1993). Poor Discipline: Parole and the Social Control of the Underclass, 1890-1990. Chicago: University of Chicago Press.

SOS RACISMO (2001). Ejido: Racismo y Explotación Laboral. Barcelona: Icaria.

- (2002). Informe Social 2002 sobre el Racismo en el Estado Español. Barcelona: Icaria Editorial.

TOBARra, Sebastián (2002). «Una fuente de riqueza». El País, June 16: 10.

«Un Nuovo Assunto su Quattro Sará Extracomunitario». La Gazzetta del Mezzogiorno, July 14, 2002: 14 .

Young, Alison (1996). Imagining Crime: Textual Outlaws and Criminal Conversations. London: Sage Publications.

ZINCONE, Giovanna (2001). Secondo Rapporto sull'Integrazione degli Immigrati in Italia. Bologna: Il Mulino. 